\title{
Norse Mythological Archetypal Analysis to The Death of Balder by Johannes Ewald
}

\author{
Junlin Luo ${ }^{1, *}$ \\ ${ }^{1}$ Department of Literature, Uppsala University, Uppsala, Uppsala County, Sweden \\ *Corresponding author. Email: junlin.luo.2054@student.uu.se,
}

\begin{abstract}
Johannes Ewald's The Death of Balder contains many elements from Old Norse mythology. By using Jungian archetypal theory and Frye's theory of archetypal literary criticism, this paper examines the representation of Norse mythological archetypes embodied in The Death of Balder. Through an analysis of the characterization and narrative structure in Ewald's play, the focus is on the correlation between Old Norse mythology and The Death of Balder. A fundamental element of this association is conclusively considered to be the decisive and archetypal role of Old Norse mythology in the composition of the play.
\end{abstract}

Keywords: The Death of Balder, Norse mythological archetypes, Old Norse mythology

\section{INTRODUCTION}

Danish national dramatist Johannes Ewald's famous play The Death of Balder (1775) depicts the tragic love story of Balder, Nanna and Hother. In this play, apart from the main characters, the narrative structure and the myriad of symbols and images clearly resemble the structure of Old Norse mythology. As John L. Greenway has argued, Norse mythology not only plays a metaphorical role in Ewald's The Death of Balder but is also to some extent the source of the play's worldview [1].

A variety of studies have analysed the reappearance of Norse mythological elements in modern literature from two perspectives: firstly, by analysing the representation of Norse mythological elements in sentimental literature and a review of lyrical techniques; and secondly, by examining Norse mythological figures in literary nationalism, in which Norse elements are observed as symbols of national identity. Both of these investigative paths consider questions about the function of Norse mythological elements in the creation of modern literary works, but neither addresses the archetypal significance of Old Norse myths. This paper will draw on Jungian archetypal theory and Frye's archetypal literary criticism to argue for the archetypal relevance of Norse mythological elements to Johannes Ewald's The Death of Balder. In order to achieve this research aim, it will identify the archetypes of Norse mythology in the script of The Death of Balder, thus revealing how these Norse mythological archetypes influenced and even determined the creation of the play.

An "archetype", according to psychologist Carl Jung, is a recurring figure in history, essentially a mythological figure [2]. He proposes that our "collective unconscious" includes a variety of archetypal scenarios, each contributing to the mythic universe as a whole [3]. In this sense, it is reasonable to use Jung's theory of archetypes to explain the relevance of characterisation between Old Norse mythology and The Death of Balder. The Canadian literary critic Northrop Frye adapted Jung's "archetypal" assertion and developed the theory further in the field of literature. According to him, myth is the central informative force that gives the oracle its archetypal story, and therefore myth is archetypal [4]. Hence, "archetype" as a literary term refers to recurring narrative structures, modes of action, character types, themes and symbols. Archetypal literary criticism is therefore about examining how archetypes influence and even determine the form and content of a literary work by focusing on the analysis and interpretation of a text's symbols, images, storylines and characters.

In the light of the above explanation, the following analysis will be divided into two parts: the first part focuses on the reproduction and displacement of archetypal characters in The Death of Balder. The second part examines the play's specific representation of the narrative structure of the archetypal character in Old Norse mythology. 


\section{REPRODUCTION AND DISPLACEMENT OF ARCHETYPAL CHARACTERIZATION IN THE DEATH OF BALDER}

According to Frye, archetypes in literature can be generally classified into three organizations: undisplaced myth, romantic tendency and tendency of realism [5]. I will analyze the archetypal characterization in the script based on the first two categories.

\subsection{Un-displaced archetypal characters}

The term "un-displaced archetype" refers to the presence of a mythical archetype in the literary work in its original form. For instance, gods and devil, heaven and hell. In Ewald's script, Odin, Loki and Thor belongs evidently to this category.

\subsubsection{Odin: Wise Old Man}

In Old Norse myth, Odin provides the archetype of a "wise old man". According to Jung, wise old man is the superior master and teacher, who symbolizes the preexistent meaning [6]. In Old Norse myth, Odin is the lord of all Æsir, he has supernature power and the ability of prediction. In the Prose Edda, he is depicted as the greatest ruler: "It is my belief that this Odin and his brothers are the rulers of heaven and earth... whom we know to be the greatest and most famous..." [7]. As an archetypal character, his function is to offer guidance or instructions and even motivate other characters. Moreover, he is not always actively involved in the character's action, only interferes when needed [8]. He sacrifice one of his eyes in Mimer's well to gain wisdom, so that he acquires the ability of prediction. Relying on this precognition, Odin is able to foresee the misfortune in the future and take precautions. For example, he anticipates the Ragnarök, in order to prevent this disaster, he builds Valhalla and sends the Valkyries to bring in the einherjar. Therefore Odin indeed provide the archetype of wise old man.

Although there are not many descriptions of Odin in Ewald's work, it is still quite obvious that the image and function of Odin, as the archetype of wise old man, has remained unchanged. This can be identified in the first act of the drama. When Thor finds Balder warning him about his fate, he says: "On my lips I bear the words of Odin...A tree...can slay thee" [9]. In true sense, Odin dose not made a debut in the drama, but it's evident from these lines that he, as a wise old man, foresees Balder's misfortune, and the precaution he takes is to sends Thor to warn Balder.

\subsubsection{Loki: Trickster}

Loki acts as an archetypal trickster in Old Norse myth.
According to Jung, a typical trickster is the combination of fondness of sly jokes and malicious prank and power of shapeshifting [6]. In Old Norse myth, Loki is half-god, half-giant, and has the capacity to change his shape and gender. He is not actually a god, but he lives among the gods in Asgard and he has some kind of divine nature of his own [8]. Although he occasionally utilizes his cunning to provide Æsir gods benefit, like Thor's powerful hammer Mjönir, his bad-mindedness eventually plunged disasters to Asgard. In Chapter XV of The Prose Edda, he transforms into a woman, successfully tricks Frigg, and learns from her that only mistletoe can kill Balder, which then leads to the death of Balder [7].

In The Death of Balder, Loki's personality traits and ability has remain unchanged. He deceives Balder and Hother using his shape-shifting power. In Ewald's script, Loki transforms into an old man and a famer respectively, wandering between Balder and Hother, using their love for Nanna to inflame the conflict and hostile between them:

\section{LOKE: Pretty folly!}

Balder invisible! the handsome half-god!

HOTHER: What! Balder, son of Odin? He her lover?

O heaven! Say, where is he? where? [9]

Hence, in order to realize his machination, he leads Hother to find the only weapon that can kill Balder. Apart from his cunning personality, Loki has the same function in the development of the plot as he does in Old Norse myth. He is the key character who ties Balder and Hother together and he indirectly contributes to Balder's tragedy. As John L. Greenway claims in his essay, on mythological level, Loki's machinations are a part of the unbroken chain that ends at Ragnarök, so he's action is "fated", or in other words determined by the Old Norse myth [1].

\subsubsection{Thor and Frigg: Hero and Mother}

Thor has the archetype of "hero" in Old Norse myth. Hero, as Jung claims, is an archetypal character whose main feat is to overcome the monster of darkness [6]. Thor is precisely such kind of archetype, he possesses powerful weapon and defend Asgard against the invasion of the giants and monsters. In the Prose Edda, Thor "gets great renown by slaying the Midgard-serpent but retreats only nine paces when he falls to the earth dead, poisoned by the venom that the serpent blows on him." He is very upright and brave but also slightly short-tempered. As Meletinskij mentioned in his study, the other manifestation of Thor's epical personality is his wrath [10]. So the interplay and combination of these traits and characteristics comprise Thor's archetype of hero.

Frigg is a representation of "mother" archetype in Old Norse myth. The Jungian mother archetypal character is 
frequently associated with caregiver and the image of safety and implies protection [6]. Frigg is a mother who will protect her offspring at any expense. In the Prose Edda, after hearing of Balder's nightmare about death, Frigg travels around the world and make everything she can thinks of to swear that they will never hurt Balder [7].

Interestingly, in Ewald's script, Thor becomes a hybrid of these two archetypes; in other words, he not only has the short-tempered personality of Thor, but also a Frigg-like protector function. In The Death of Balder, Thor serves as a caregiver who devotes to protect Balder from misfortune just as what Frigg does in the myth. But he does this in his own way, he finds Balder and warns him over and over again: "Now, Balder, hear my word, and fly from Nanna" [9]. Thor's short temper is evident in this line, and we can also identify his eager willingness to protect Balder that parallels a caring mother.

\subsection{Tendency of Romantic: Balder and Hother}

Balder and Hother belongs to the second category of archetype, that is the tendency of romantic. According to Frye, the romantic tendency refers to implicit mythical patterns in a world more closely associated with human experience [5]. In other words, this type of displacement changes the form of expression of the mythical archetypes, and then incorporates the characters and plots in the literary work. However, to put it in a more specific way, it is more plausible to that the displacement of Balder and Hother actually falls between the undisplaced categories and the tendency of romantic. The rationale for this statement is that the development of plot involving Balder and Hother is based on two dimensions: the mythical world and the romantic world.

In terms of mythical dimension, Balder's role remain un-displaced. In Old Norse myth, Balder is the son of Odin, and god of light. His death is the prelude of the chain that ends with Ragnarök. This function has remained un-displaced in Ewald's work. This can be identified in Thor's words: "When he's rejected by a prophet's daughter, that year shall see the spear which holds his ruin, shall see the gods in grief, and Odin weeping"[9]. The meaning that lies on the surface of this line is that if Balder dies, all the gods including Odin will feel sorrowful. But the hidden meaning is that all the tears are not only for Balder but also for the end of the world is coming. So, this line in fact indicates that the death of Balder is the trigger of Ragnarök.

While in terms of the romantic level, i.e., what happens in the human world, the archetypal dichotomy between Balder and Hother in the Old Norse myth is overturned. Which is to say, Balder's and Hother's position in the hierarchy system that raised from the dichotomy in Old Norse myth has reversed. In Old Norse myth, Balder and Hother are presented as binary oppositions: as the god of light, Balder is eminently handsome and beloved, all the gorgeous words are utilized to describe him: "... of him good things are to be told. He is the best, and all praise him. He is so fair of face and so bright that rays of light issue from him" [7]. While Hother is the god of dark and is isolated in Asgard for his ugly appearance, as the Prose Edda depicts: "Hother stood far to one side in the ring of men, because he was blind " [7].

Things are totally contradictory when it comes Ewald's depictions of them. In The Death of Balder. Balder became the one who is not beloved and isolated, because he loves Nanna but Nanna and Hother love each other. Balder is described as a frustrated and helpless half-god, tortured by love. Thus, it is proper to say that on the romantic dimension, Balder is the displacement of Hother in Old Norse myth.

\section{AUTUMN AND WINTER: THE NORSE MYTHOLOGICAL ARCHETYPAL NARRATIVE STRUCTURE IN THE DEATH OF BALDER}

\subsection{Frye's Theory About Mythical Narrative Structure in Old Norse Myth}

Narrative structure includes the content and form of a story, and most importantly, it shows the development of plot in a story. For example, which are the key conflicts, what should happen in which occasion. Frye's theory of narrative structure underlines this internal order in literary works. In the third essay in Anatomy of criticism, Frye expounds his idea of the cyclical movement of literature. He asserts that literature itself develops like an organism, its development is identical with the process of life. According to him, the fundamental form of process is cyclical movement, the alternation of success and decline, effort and repose, life and death which is the rhythm of process [5], and it is myth that attach archetypal significance to this process. Then he divides the cyclical movement into four stages which are identical with the four seasons in nature: romance (spring), comedy (summer), tragedy (autumn), irony or satire (winter). Based on this, Frye pioneers four narrative categories of literature that "broader than, or logically prior to, the ordinary literary genres" [5]. Thus, it is probable to assert that almost all the narrative structure in the modern literary works is formed or determined by the original structure provided by the myth, and The Death of Balder makes no exception.

\subsection{The Archetypal Narrative Structure in Old Norse myth}

As an ancient Nordic myth, the development of plots basically coincides with the four development phases that Frye has come up with. The spring phase is myth of birth, of creation and (because the four phases are a cycle) of 
the defeat of the powers of darkness, winter and death [4]. The beginning of the Old Norse myth is precisely a creation myth. It depicts how Odin and his brothers defeat the giant Ymer and create the world and Asgard out of his body: "The sons of Bor slew the giant Ymir...They took the body of Ymir, carried it into the midst of Ginungagap and made of him the earth" [7].

The summer phase is the archetype of idyll, and it is marked its extraordinarily search for some kind of imaginative golden age in time or space [5]. In the Prose Edda, the chapter after the creation story is called The First Work of the Asas.The Golden Age. This chapter, as well as the following chapter, presents the opulence and fabulousness of Asgard. For example, this is how the building looks like in Asgard: "Their first work was to erect a court... That is the best and largest house ever built on earth and is within and without like solid gold" [7]. Another manifestation of the "golden age" phase in Old Norse myth is the magic apple which keeps all the Æsir young. These apples are called the medicine to bar old age, and gods eat when they grow old, and then they become young again [7].

The autumn phase refers to sunset and death, it is the archetype of tragedy. It's myth of the dying of god, of violent death and sacrifice and of the isolation of the hero. In Old Norse myth, the death of Balder is such kind of tragedy. As Frye writes in Anatomy of criticism, even though the tragic hero may conduct some effort to reverse the bad situation, he cannot simply rub a lamp and summon a genie to get him out of his trouble. The hero might be great as compared with us, but he became small and helpless when comparing with something like fate, accident or fortune [5]. In Old Norse myth, although the one who tries to prevent Balder from dangers is not himself, some attempts has been taken in order to avoid his death. As it is said in the Prose Edda, after Balder dreamed the dangerous dream about his death, the Æsir took counsel together and decided that they should take measures to protect Balder from all kinds of harm. "So, Frigg exacted an oath from fire, water, iron and all kinds of metal, stones, earth, trees, sicknesses, beasts, birds and creeping things, that they should not hurt Balder" [7]. But Balder die eventually, as it is his "fate".

The winter phase contains darkness and dissolution. It's the myth of the return of chaos, and the defeat of the hero [4]. In Old Norse myth, after Balder's death, comes the Fimbul-winter, and it lasts for three years. In the Prose Edda, this winter is depicted like this: "when snow drives from all quarters, the frosts are so severe, the winds so keen and piercing, that there is no joy in the sun. There are three such winters in succession, without any intervening summer" [7]. So Balder's death is not only his own fate, it's also connected with the destiny of world. As Rasmus Anderson writes in his study, The winter following the death of Balder is not an ordinary winter, but the Fimbul-winter, which is followed by the destruction of the world [7]. The Fimbul-winter is the prologue of a catastrophe, in which sun and moon are devoured by two wolves, and "the earth and the mountains will shake so violently that trees will be torn up by the roots, the mountains will topple down, and all bonds and fetters will be broken and snapped" [7]. All the Æsir have a fight with the monsters such as the Midgardserpent and the Fenris-wolf. In the end, the whole world is burned in fire giant Surt's fire. This catastrophe is called Ragnarök, which is identical to the "Götterdämmerung myths" that Frye has mentioned in the winter phase [7].

\subsection{The Archetypal narrative structure in The Death of Balder}

The whole story in drama The Death of Balder is a tragedy which corresponds to the autumn phase. Although Ewald has made many subtle modifications on the characterization and the plot, making the script look like a brand-new romantic story about Balder's death, he fails to escape the narrative structure from the Old Norse myth. This is evident in the characterization's motivation of action. At first glance, we might say that Balder's death in the drama is just an accident, and that it is because he cannot stop his love for Nanna and so the prediction that Thor brings to him comes true. But if we conduct a carefully analysis of the plot, we will find that it is not that simple. It's true that the confliction and fights between Balder and Hother eventually leads to the death of Balder, and the confliction comes from their love for Nannan and their jealousy for each other.

We may simply assume that all the plot in the drama is driven by character's action, but if we try to explore the motivation for the actions of the characters, finding a plausible answer can be challenging. Why Loki is so lucky to find the only weapon that could kill Balder and then lead Hother to find them? Did Hother really kill Balder by accident? It may seem difficult or even impossible to find the explain from the characterization level, because in Ewald's drama, the figure of Balder and Hother cannot simply be classified as good or evil, so do the motivations behind their action. A plausible answer is "they are fated to do so", or in other words, the plot must develop in this way, as Balder's death is a key point in the unbroken chain that leads to Ragnarök in the Old Norse myth. When the consequences are elevated beyond good and evil (and, indeed, beyond human will), the drama begins to develop a fateful quality associated with much great tragedy [1].

\section{CONCLUSION}

In summary, Ewald's The Death of Balder contains many archetypes from the Old Norse myth. Drawing on the Jungian archetype theory and Frye's archetypal literary criticism, it can be seen that this archetypal 
relevance has its demonstration mainly in the characterization and narrative structure in The Death of Balder. Relying on the worldview setting in the Old Norse myth, Ewald uses his exquisite technique to adapt these archetypes into his own drama, which in fact provides a new variation of the Old Norse myth. On one hand, myth constructs the creation of literary works, by determining their characterization and structure. On the other hand, since the literary works are more or less the displacement and modification of the myth, they ensure myth's eternal existence as well as endue myth with new contemporary connotation.

\section{REFERENCES}

[1] Greenway, J. L. (1970) The two worlds of Johannes Ewald: Dyd vs. myth in Balders død. Scandinavian Studies, 163: 394-409.

[2] Jung, C. G. (1995) The Spirit in Man, Art, and Literature. Princeton University Press, Princeton.

[3] Walker, S. (1994) Jung and the Jungians on Myth. https:/ebookcentral.proquest.com/lib/uu/detail.acti on?docID $=1666847$.

[4] Frye, N. (2016) The archetypes of literature. In: The Educated Imagination and Other Writings on Critical Theory 1933-1963. University of Toronto Press, Toronto. pp. 120-135.

[5] Frye, N. (1957) Anatomy of Criticism: Four Essays. Princeton University Press, Princeton.

[6] Jung, C. G. (2014) The Archetypes and the Collective Unconscious. Taylor and Francis, Oxfordshire.

[7] Sturluson, S. (2006) Younger Edda. https://www.gutenberg.org/cache/epub/18947/pg18 947-images.html.

[8] Vehkomäki, A. (2020) Mythological archetypes in the legendarium of J.R.R. Tolkien and J.K. Rowling's Harry Potter Series. http://jultika.oulu.fi/files/nbnfioulu202011183137.pdf.

[9] Ewald, J. G. (2004) The Death of Balder. https://www.gutenberg.org/cache/epub/13879/pg13 879-images.html.

[10] Meletinskij. E. (1977) Scandinavian mythology as a system of oppositions. In: Jason, H., Segal, D. (Eds.), Patterns in Oral Literature. De Gruyter Inc., Berlin. pp. 251-260. 